DOUTRINA

\title{
O Juiz em Face do Atual Regime de Acumulação de Cargos
}

35.081 .71

\section{CORsindio MONTEIRo. DA Silva}

É postulado constitucional a teoria célebre de Montesquieu, da independência dos Podêres da União, que ccrexistem harmônicamente (art. 38). Outro princípio adotado pela Carta Magna é o da vedação de acumular cargos públicos (art. 185), problema em que, de velha data, se debater. legisladores portuguêses e brasileiros, no sentido de coibir abusos por parte dos colecionadores de empregos em prejuízo da administração e dos outros cidadãos que, muitas vêzes ccrm maior capacidade, relutam por conseguir um emprêgo público. Êste princípio visa, ainda, a assegurar o cumprimento do preceito constitucional inscrito no art. 184 que afirma serem os cargos públicos acessíveis a todos os brasileiros.

A salvaguardar aquêle dogma da ciência constitucional, isto é, o da separação dos Podêres, a Constituição Federal de 1946 preceitua que o cidadão investido na função de um dêles não poderá exercer a de outro $\left(\S 1 .^{\circ}\right.$ do art. 36).

Assim, além da proibição genérica de acumular cargos públicos, há, também, a vedação específica do exercício de funções em mais de um Poder.

Permite, todavia, a Magna Carta o desempenho simultâneo de funções nos vários Podêres, ou em um só, dentro das exceções nela previstas. Quais são elas? As inscritas no item I, do art. 96 , e no art. 185 da Constituição, ou mais pròpriamente: a acumulação do cargc de juiz com magistério secundário e superior; a de dois cargos de magistério, e a de um cargo de magistério com outro técnico ou científico; estabelecendo, ainda, como requisito para a permissibilidade da acumulaçãc que haia correlação de matérias e compatibilidade horária, exigindo a lei horária, para a hipótese do juiz, sòmente a compatibilidade de horários, consoante a Lei n. ${ }^{\circ} 1.711$, de 28 de outubro de 1952, que regulamentou o preceito constitucional.

Obedecendo, ainda, àqueles princípios, talvez mais assegurando o primeiro, vale dizer, o da independência do Podêres, proibiu a Lei Maior (art. 48) aos membros do Poder Legislativo, ou melhor, aos deputados e senadores,

"I - desde a expedição do diploma:

a) celebrar contrato com pessoa jurídica de direito público, entidade autárquica ou sociedade de economia mista, salvo quando o contrato obedecer a normas uniformes; 
b) aceitar nem exercer comissão cu emprêgo remunerado de pessoa jurídica de direito público, entidade autárquica, sociedade de econcmia mista ou emprêsa concessionária de serviço público;

II - desde a posse:

a) ser proprietário ou diretor de emprêsa que goze de favcr decorrente de contrato com pessoa jurídica de direito público, ou nela exercer função remunerada;

b) ocupar cargo público do qual possa ser demitido ad nutum;

c) exercer outro mandato legislativo, seja federal, estadual ou municipal;

d) patrocinar causa contra pessoa jurídica de direito público".

Tais proibições se estendem, no que fôr aplicável, ao Presidente e ao Vice-Presidente da República, aos Ministros de Estado e aos Membros do Pcder Judiciário, ex-vi do art. 197 do mesmo diploma legal.

Como sói acontecer, a nossa legislação estabelece um princípio rígido, embcra não absoluto, para logo em seguida abrir exceções que, muitas vêzes, desfiguram a regra geral. No que tange às exceções à vedação constitucional de acumular cargos públicos, por exemplo, em que pese ao imperativo da proibição, a legislação cria tantas exceções à regra geral que já são poucos os que não podem exercer dois cargcis. Por outro lado, os pressupostos da permissibilidade não foram colocados, queremos crer, em têrmos que garantam a exata inteligência do espírito que ditou a norma de exceção, assunto a que nos propomos voltar oportunamente.

Com efeito, a um membro do Poder Judiciário, a um magistrado é vedado exercer, "ainda que em disponibilidade, qualquer outra função pública", entanto assegura-lhe a Constituição o desempenho do magistéric secundário e superior, função do Executivo, "e os casos previstos nesta Constituição". A Lei n. $^{\circ} 1.711$, de 28 de outubro de 1952, que disciplinou o mandamento constitucional, eximiu, por sua vez, o magistrado da observância da correlação de matérias, pressuposto constitucional ao nosso ver indeclinável, só dêle exigindo a compatibilidade horária.

Qual a razão por que se não exigiu do Juiz a correlação de matérias, isto é, que o magistrado só lecione matéria de Direito? Dir-se-á que tal aconteceu em virtude do próprio dispositivo constitucional que the facultou - exercício de magistéric secundário, onde não há matéria jurídica. Isto, entanto, não parece, com a devida vênia, uma exceção odiosa, que os próprios beneficiados deveriam repudiar?

A mens legis, ao que parece, foi o de propiciar ao magistério o aproveitamento dos ensinamentos que um juiz the pode trazer com especial vantagem, mormente no interior do País, e aprimorar a cultura do magistrado na prática do magistério. Homines dum docent, discunt. Assim só poderia o juiz prelecionar matéria jurídica, que se não inscreve no currículo secundário, escapando ao nosso entendimento a extensão da exceção preccnizada pela Carta Magna de 1946 e reproduzida na citada Lei . $^{\circ} 1.711$, de 1952 (Estatuto dos Funcionários). Salvo se o legislador tinha diverso entendi- 
mento do que seja "ccirelação de matérias" ao invés daquele perfilhado pelo Decreto n. ${ }^{\circ} 35.956$, de 2 de agôsto de 1954.

Há que atentar para a proibição constante da letra b, do item II, do art. 48, da Constituição Federal, e das restrições contidas na Lei n. ${ }^{0}{ }^{1.711}$, de 28 de outubro de 1952, quando se cogitar de acumulação pü parte de magistrados.

Poderá, assim, o juiz acumular, desde que seja:

a) com um cargo de magistério secundário ou superior,

b) que haja compatibilidade de horários e

c) que não seja demissível ad nutum.

É de indagar se o juiz púderá exercer o cargo de Diretor de um colégio ou de uma Faculdade de Direito ou de Filosofia. Em princípio, parece-nos que não, em face da lei, que só faculta ao magistrado exercer cargo de magistério. Se o cargo de Diretor não fôr inerente ao de professor, e sim de mera administraçãc e de livre escolha da autoridade executiva, sem prévia indicação da congregação, não vemos possibilidade legal de o juiz exercê-lo. Será um cargo em comissão como outro qualquer, sem aquelas características que singularizam o exercício por um professor escolhido entre seus pares, em lista tríplice, e que constitui verdadeiro mandato por determinado período de tempo. Nessa ordem de considerações, um juiz poderá ser, igualmente, Reitor de uma Universidade. Cumpre verificar, entanto, o regulamento do estabelecimento oficial de ensino, para se constatar se o cargo de Diretor ou de Reitor deriva de um mandatc; da mesma forma como ocorre, por exemplo, na Universidade do Brasil.

Mesmo em se tratando de cargo de magistério secundário ou superior, é defeso ac juiz desempenhá-lo, desde que não seja vitalício ou do qual seja demissível ad nutum, isto é, demissivel ao livre arbítrio da autoridade administrativa sem qualquer outra garantia em face do poder discricionário da administração.

A Constituição Federal quis, com isso, salvaguardar a independência dos podêres, a autoridade incontrestável da toga, impedir a corrupção, assegurar a liberdade, evitar a arbitrariedade e a tirania.

Já dizia Montesquieu que "se o poder de julgar estiver unido ac poder executivo, o juiz terá a fôrça de um opressor" e, poderíamc's acrescentar, a fraqueza de um mísero escravo, confcrme as circunstâncias...

E' vedado, ainda, ao magistrado desempenhar um cargo de magistério secundário e mais um de magistério superior. E' certo que a Constituição Federal diz ser defeso ao juiz exercer quaisquer cargos "salvo o magistério secundário e superior". Å primeira vista e pela interpretacão literal, ocorreria para loğo, que o juiz pudesse exercer três cargos, porém seria indefensável essa conclusão em face da sistemática constitucional, mesmo porque a Carta Magna. como já tivemos oportunidade de acentuar (Parecer in Processo n. ${ }^{\circ}$ 6.856-56 - C.A.C. - D.O. de 26-XI-957 (Sec. I), p. n. ${ }^{\circ}$ 26.539), veda a acumulacão de cargos, ccm exceções que numera, e ao magistrado, "ainda que em disponibilidade, aualauer outra função pública, salvo o magistério secundário e superior" (art. 96, n. ${ }^{\circ}$ I). 
Ora, a mens legis seria admitir, excepcionalmente ao juiz, o exercício de outra função pública, especificado no próprio art. 96 da Constituição, qual seja o magistério, sendo o nosso entendimento, perfilhado pela Comissão de Acumulação de Cargos, que a expressão "secundário e superior", naquela frase, representa um todo atributivo compostc do objeto "o magistério", completivo direto êste dc' verbo "exercer", oculto por zeugma, e a partícula e materialmente um conectivo com função lógica disjuntiva ou alternativa entre idéias incompatíveis ou alternadas. Salientamos, entãc; que aquela proposição, verdadeiramente, era mais para ser sentida que analisada gramaticalmente, considerando-se os demais elementos que concorrem para a inteligência do texto legal.

Acresce que o próprio Poder Legislativo, ao elaborar a Lei n. ${ }^{\circ} 1.711$, de 28 de outubro de 1952 (Estatuto des Funcionários) e quando da reprodução do preceito constitucional em exame, evidenciou a procedência de nossa interpretação, no sentido da disjunção ou alternação, entre idéias incompativeis, visto que admitiu aquela permissibilidade "de cargo de magistério, secundário ou superior, com o de juiz", nos têrmos do parágrafo único, item I, do art. 185 , do referido diploma legal regulamentado pelo Decreto $n .^{\circ} 35.956$, de 2 de agôsto de 1954, que, pcr sua vez, emprestou o mesmo entendimento compatível com o espírito que ditou a norma constitucional. A interpretação da excecão há que obedecer ao princípio dirigente a que ela se subordina. $\mathrm{E}$ o princípio geral é o da vedação da acumulação de quaisquer cargcs.

Reafirmamos que interpretar de maneira diversa será ampliar em demasia aquilo que a Constituição já concede, em caráter excepcionalíssimo, aos juízes, quando se lhes dispensa, inclusive, a verificação do requisito de correlação de matérias, exigido, inapelàvelmente, mesmc aos catedráticos, dentro dos rígidos princípios da restrição legal.

A Lei n. ${ }^{\circ} 1.711$, de 1952, foi sábia, nesse particular, quando alterou a faculdade de o juiz exercer um ou outro cargo de magistério e estabelecendo a compatibilidade horária, que seria uma expressão sem sentidc prático caso não se fizesse disjunção entre o magistério secundário e o superior.

Foi, dêsse modo, uma interpretação legítima do texto contitucional, que atendeu a razões de ordem prática e de ordem mcral.

Atentaram bem para o espírito da Constituição Federal os constituintes de Pernambuco e do Rio Grande do Sul quando, ¿o postularem sôbre o mesmo assunto, apuseram expressamente a disjuntiva ou, de igual com o legislador ordinário do Estatuto dos Funcicnários Públicos Civis da União, e cuios dizeres, dos respectivos artigos das constituições estaduais, pedimos vênia para transcrever.

\section{Da Constifuiçãc do Estado de Pernambuco:}

"Art. 80. Os desembargadores e Juízes, ainda que em disponibilidade, não poderão exercer qualquer outra função pública, salvo o magistério secundário ou superior e os casos previstos nesta Constituiçãc, sob pena da perda do cargo judiciário e de tôdas as vantagens correspondentes". 
Da Constituição do Rio Grande do Sul:

"Art. 107. É vedado ao juiz:

I - exercer, ainda que em disponibilidade, qualquer outra função pública, salvo c magistério secundário ou superior e os casos previstos na Constituição, sob pena de perda do cargo judiciário".

Ademais, o juiz, como professcr, estaria sujeito a uma legislação especial, aplicando-se-lhe subsidiàriamente o Estatuto dos Funcionários. Ora, se o magistrado não tem horário rígido para o seu expediente, está, nada obstante, obrigado ao regime de 18 horas semanais de trabalhc's escolares, na conformidade do Decreto-lei n. 2.895 , de 21 de dezembro de 1940. Se ao juiz the fôsse legalmente possível exercer êsses três cargos, o desempenho dêles seria impraticável e danoso à administração, inclusive à da justiça, sôbre ficar o juiz impossibilitado materialmente de cumprir o munus que the pode ser impôsto de servir à justiça eleitoral. A admitir-se pudesse desempenhar dois cargos de magistério, sendo-lhe, como se sabe, irrecusável a função de magistrado eleitoral, teríamos o absurdo de ver a lei assegurar ao juiz o exercício de quatro cargos (pela Constituição do Paraná (art. 58), poderia o juiz desempenhar cinco cargos, pois que lhe é assegurado o exercício, também, do Iuagistério primário), em detrimento de muitos cidadãos que não tiveram o privilégio sequer de ter um cargo técnico ou científico com que pudessem acumular com outro de magistério, e em que houvesse, dentro dos rigores da lei, correlação de matérias e compatibilidade horária.

Vale considerar que a Lei . $^{\circ} 1.711$, de 1952 , preceitua que a acumulação de boa fé obriga o funcionário, que acumulava ilegalmente, a optar por um dos cargos, e, no caso de comprovada má fé, perderá os dois cargos e res. tituirá c que houver percebido indevidamente (art. 193, par. único). No caso do juiz que acumula ilegìtimamente, rão se há de aplicar a penalidade inscrita no parágrafo $10^{\circ}$ do art. 48 , da Constituição Federal, ou no item I, in fine do art. 96, do mesmo diploma legal (reproduzida em quase todas as constituições estaduais), sem se ccnsiderar, primeiremente, como é óbvio, o elemento subjetivo que o exame do ilícito comportar.

Apreciando a acumulação por êste aspectć; se se verificar a incidência de boa fé, é de se aplicar o preceito ínsito no art. 193, da Lei n. ${ }^{\circ} 1.711$, de 1952, vale dizer, o magistradc optará por um dos cargos. Notada a má fé, em processo regular, não só perderá o cargo judiciário, na conformidade do citado art. 48 da Constituição combinado com o item I, in fine, do art. 96, do mesmo diploma legal, e sim ambos os cargos acumulados, restituindo c que houver percebido indevidamente.

Talvez se possa argüir de "inconstitucional" esta solução na hipótese de verificacão de má fé, embora ao iuiz, com muito mais razãc, não é dado alegar ou nêle supor $c$ desconhecimento da lei e do seu regime funcional, entan+o, certamente, não the será oposta nenhuma objecão quando da ocorrência de boa fé, em que propugnamos uma solucão mais em harmonia ccm a hermenêutica e com as normas de aplicarão da lei. que não a que, à primeira vista, nos possa sugerir o texto da Constituição. 
No casc de se não aplicar ao magistrado o regime estatutário federal, é de se lhe dar, ainda assim, tratamento dentro do critério aventado, na hipótese de ocorrência de boa fé, em virtude de aplicação analógica. Seria a analogia in bonam partem. Nem se argumente que, em matéria disciplinar, nãc se aplica o princípio analógico, da mesma forma como ocorre com o direito penal, uma vez que tal solução se impõe, mesmo porque não desatende ao princípio da benignidade da pena ou do postulado da garantia individual, antes com êles se compadece. A analogia, aqui, beneficiaria ao magistrado que, de boa fé comprovada, acumulasse indevidamente, resultando a sua aplicação de verificação de paridade ou semelhança do caso omisso com outros de acumulação proibida, que se disciplinam por preceito legal, considerando, ainda, o fim da própria lei, que nãc tem interêsse maior na punibilidade e sim que colima evitar acúmulo de cargos em prejuízo da administração e garantir a independência dos Podêres.

Tanto é assim, que se não justifica que um servidor, que não magistrado, poderia optar por um dos cargos, no caso de verificação de acumulação ilegítima, só incidindo na pena de perda dos dois cargos e restituição do que recebeu indevidamente apurada a má fé, e ao magistrado, em qualquer dos casos, se aplicasse, tão só, e sempre, a pena de perda do cargu judiciário. In re dubia benigniorem interpretationem sequi non minus justius est quam tutius é um velho preceito de hermenêutica que não perdeu sua atualidade, e a que o aplicador da lei não pode estar alheio.

Cümpre, ainda, considerar que o magistrado - juiz, desembargador, ministro do Supremo Tribunal Federal, juiz do Tribunal Federal de Recursos - poderá integrar os órgãos da justiça eleitoral dentro da hierarquia estabelecida pelo art. 109, da Constituição Federal, e obedecendo ao critério do art. 110, dessa nossa lei básica.

Se um magistrado, per exemplo, indicado pelo Tribunal de Justiça, na forma do item II, do art. 112, da Carta Magna, fôr nomeado pelo Presidente da República para integrar um Tribunal Regional Eleitoral, incorrerá em acumulação proibida? Não, porque suas funções não cc'nstituem cargo público, dentro da conceituação do art. $2 .^{\circ}$ do Decreto n. ${ }^{\circ} 35.956$, de 2 de agôsto de 1954 , com a redação dada pelo Decreto n. ${ }^{\circ} 36.479$, de 19 de novembro de 1954 , e sim encargo ou munus público, à vista de suas característica peculiares e excepcionais, considerada, ademais, sua obrigatoriedade e temporaneidade ex-vi do art. 114 da Constituição Federal, combinados com os artigos $3 .^{\circ}$ e 185 da Lei n..$^{\circ} 1.164$, de 24 de julho de 1950 (Código Eleitoral).

Conseqüentemente, refoge ao princípio da vedação constitucional de acumular cargos públicos o exercício de quaisquer cargos com as funções de magistrado eleitoral.

Poderá ocorrer, ainda, a hipótese de certos servidores pretenderem exercer o cargo de juiz-substituto, que, em certos Estados da Federação, como o do Rio de Janeiro, tem um regime próprio, isto é, a funçãc de juiz-substituto só é exercida durante as férias e impedimentos do titular, sòmente nessas 
ocasiões recebendo os vencimentos, não sendo por concurso o provimento da função.

Respondendo a uma consulta de um servidor do Ministério da Viação e Obras Públicas (Manipulante Postal) que, no Estado do Rio de Janeiro, pretendia ser juiz nas horas vagas, opinamos pela ilegitimidade da situação almejăda, uma vez que ela fatalmente incidiria em acumulação proibida, parecer êsse que lugrou aprovação da Comissão de Acumulação de Cargos e do Diretor-Geral do Departamento Administrativo do Serviço Público.

Com efeito, a temporaneidade do exercício da função de juiz-substituto, não só do biênio por que é ncmeado, senão, também, do período de substituição efetiva dos juízes de direito, não desnatura ao nosso ver, a conceituação legal do cargo, dentro da qual se inscreve, nem a configura como "serviçcs eventuais", o que seria, além do mais, uma aberração. Assim, no caso, a descontinuidade no desempenho da função não descaracteriza o provimento em cargo público.

Ressaltamos ser, ademais, irrelevante o fato de o juiz-substituto estadual só perceber vencimentc's nas férias e impedimentos do titular, mesmo porque seria desprovido de sentido prático concluir-se que o juiz-substituto só poderia acumular enquanto não estivesse em exercício. Intellectus absurdus est vitandus. Nem seria admissível optar pelos vencimentos do juiz-substituto, pôsto que a Constituição e a legislaçãc específica vedam a acumulação de carǵos e não a de vencimentos, e sim que a opção se devia processar entre os cargos inacumuláveis, desvinculando-se de um dêles, uma vez que o não recebimento de vencimentos não aliena do serviço público ao funcionário, e, conseqüentemente, não o exime às proibições legais.

Ao entender nosso, o consulente poderia conciliar sua função burocrática - que, ademais, não é de magistério, com a possível vocação para a função judicante, pleiteandc sua nomeação para magistrado eleitoral, desde que atendidos cs requisitos legais, a que anteriormente aludimos.

Não nos parece inoportuno, nem desnecessário, à vista de possível impertinência, a despeito das dúvidas que poderiam surgir, considerar a hipótese dos Ministros dos Tribunais de Contas da União, do Distrito Federal e dos Estados em face do regime atual de acumulação de cargos. Estamos em que não se trata de juízes, no sentido específico e próprio do têrmo, pois que não têm poder judicante, strictu sensu. Julgam contas dos responsáveis por dinheiros públicos e da legalidade dos contratos e das aposentadorias, reformas e pensões, porém não distribuem justiça. Suas decisões não possuem o imperium, a fôrça que caracterizam as decisões dos magistrados. Foi a do Piauí a única Constituição estadual que destacou em um artigo, o de n. ${ }^{\circ} 76$, (por sinal o mesmo número da Constituição Federal que dispõe sôbre os Ministros do Tribunal de Contas da União), que "sòmente os Desembargadores e Juízes de Direito são considerados magistrados", sem embargo dêsse mesmo diploma estadual conferir o nome de "juízes" aos compcnentes do seu Tribunal de Contas (art. 48). 
Já tivemos ocasião de acentuar (Vide "Arquivos do Ministério da Justiça e Negócios Intericres" - n. ${ }^{0} 64$ - dez. 1957 - pp. 42 e segs.) ser inegável terem os Ministros dos Tribunais de Contas, tanto da União, do Distrito Federal, como dos Estados, função judicante, da mesma forma como o têm outros órgãos do Poder Executivo em processos administrativos, inclusive o próprio Presidente da República, que administra justiça em matéria administrativa e constitui última instância na esfera da Administração; bem ccmo o Poder Legislativo, a quem compete julgar o Presidente da República, os Ministros de Estado e os do Supremo Tribunal Federal e o Procurador Geral da República (art. 62 da Constituição), sem que a lei, por isso, nos autorize a chamá-los de magistrdlos, no sentido estrito da expressão, ou de órgãos do Poder Judiciário, pois que essa é a dinâmica do Estado Moderno, e é que a teoria da separação dos Podêres não é absoluta, como se sabe. Poder Judiciário é o que tem por funcão precípua interpretar e aplicar a lei nos dissídios surgidos entre os cidadãos ou entre êstes e o Estado, caracterizando-se pela sua autcnomia na esfera da competência que a Constituicão the atribuiu (DARCY AzAmBUJA - "Teoria Geral do Estado" - 1955 - p. 203).

Assim, ao ccmpasso da lei, e dentro da sua esfera de atribuições específicas, o cargo de Ministro do Tribunal de Contas não é de magistrado, uma vez que, comc órgão auxiliar do Poder Legislativo, não se inclui aquêle Tribunal entre os que integram o Poder Judiciário (art. 94, da Constituição Federal).

O cargo de Ministro do Tribunal de Contas da União é acumulável com o de magistério secundário ou superior nos têrmos do art. 96, item I, da Constituição, por fôrça do que expressamente preceitua o art. $76, \S 10^{\circ}$, dêsse diploma legal.

Com efeito, a Constituição, no citado dispesitivo, ao conferir "os mesmos direitos, garantias, prerrogativas e vencimentos dos juizes do Tribunal Federal de Recursos" e o fêz quanto aos Ministros da União, ipso facto concedeu-1hes o direito de acumular carges públicos de maneira igual com aquêles integrantes do Poder Judiciário, nos têrmos do art. 96, item I, da Carta Magna. Não atribuiu, entantc, tais direitos aos Ministros dos Tribunais de Contas do Distrito Federal e dos Estados, nem os inseriu entre as excludentes enumeradas no art. 185, já que não era possível integrá-las na ressalva preconizada no art. 96 , item I, pôsto não são juízes, nome reservado ao. Poder Judiciário.

Sem embargo de se tratar de matéria constitucicnal, e em que pese à autonomia constitucional dos Estados, estamos em que, ainda que a Constituição Estadual conferisse a seus Ministres "os mesmos direitos" dos Desembargadores, não poderia, a nosso ver, ser intercalado nesses direitos o de acumular cargos públicos pois que feriria disposição expressa e peremptória da Constituição Federal que pró́be as acumulações, com exceções, que enumera, entre as quais não se inclui o de cargo de Ministro do Tribunal de Contas dos Estados com outro de magistério, do modo como o faz, expressamente, com os juízes. 
Entre os favores que a Constituição Estadual pode, inegàvelmente, conceder a seus servidores a maior do que desfrutam os federais, não se há de incluir o de acumular, que a Constituição Federal proíbe taxativamente, a não ser pelas vias das normas de exceção.

O princípio da vedação taxativa, adotado na Constituição Federal, vincula as unidades merores, sendo de notar o que, nesse sentido, estabelece o art. 18 da Carta Magna de 1946:

"Art. 18. Cada Estado se regerá pela Constituição e pelas leis que adotar, observados os princípios estabelecidos nesta Constituição".

Nem se argumente que, pelo processo analógico, poder-se-ia estender aos Ministros do Tribunal de Contas do Distrito Federal e dos Estados igual tratamento dado aos da União, pois que não se aplica a analogia em casos tais, uma vez que a enumeração inscrita na lei, que disciplina o regime de acumulação, é taxativa e excepcional. O dispositivo constitucional, que excepciona a proibição de acumular, é, por sua natureza mesma, insuscetível de extensão, e é de exegese estrita.

Analisamcs uma hipótese, na Comissão de Acumulação de Cargos, referente a uma acumulação pretendida por um ilustre Ministro do Tribunal de Contas do Estado de Santa Catarina, cuja argumentação por nós expendida poderá ser generalizada aos titulares dos Tribunais de outros Estados, inclusive o do Distrito Federal.

Aduzimos, então, que, ao preconizar a Constituição do Estado de Santa Catarina, em seu artigo 149, a criação de um Tribunal de Contas, "cujas atribuições a lei definirá", e, quando a Lei que cricu êsse Tribunal diz que "os Ministros terão os mesmos vencimentos, direitos, garantias e prerrogativas dos Desembargadcres do Tribunal de Justiça do Estado", delegou aquela podêres a esta para criação do órgão, havendo a Lei definido deveres e conferido direitos, porém dentro dos limites balizados, é evidente, pela Constituição Federal (art.18), que, no caso em referência, fixa a regra geral de proibição de acumulação de quaisquer cargos públicus (art. 185), abrindo exceções, entre as quais, como se disse, não se insculpe a de Ministros dos Tribunais de Contas do Distrito Federal e dos Estados. Dêsse modo, o preceito da Lei Estadual tem valimento apenas relativo ante a norma contida na Carta Magna.

Nem se argumente que a Constituição do Estado de Santa Catarina envolve, entre os órgãos integrantes do Poder Judiciário, "outros Juízes e Tribunais instituídos em lei" (art. 59, item V), onde, acaso, se incluiria o Tribunal de Contas, pois que êste é órgão auxiliar do Poder Legislativo, com finalidades específicas preconizadas pela Constituição Federal, que, ademais, em seu art. 94, enumera os órgãcs integrativos do Poder Judiciário:

$$
\begin{aligned}
& \text { I - Supremo Tribunal Federal; } \\
& \text { II - Tribunal Federal de Recursos; } \\
& \text { III - Juízes e Tribunais militares; }
\end{aligned}
$$




\section{IV - Juízes e Tribunais eleitorais; \\ V - Juízes e Tribunais do trabalho,}

e os das Justiças dos Estados constituem-se conforme c que ordena o art. 124, e especialmente os seus itens II, IX e XI, da Constituição Federal, sem que se vislumbre, nesses preceitos, a possibilidade de, entre êles, inserir o Tribunal de Contas Estadual.

Nem a Constituição Estadual, nem a lei ordinária poderia conceder direitos que viessem ferir frontalmente dispusição expressa da Constituição Federal o que seria, como na hipótese, ampliar exceções terminantes de um mandamento constitucional categórico de vedação de acumular cargos públicos.

Concedemos que haja entre os Ministros do Tribunal de Contas da União e cs do Distrito Federal dos Estados uma capitis diminutio nesse particular. De lege cordendo, se assim o entenderem os legisladores, pa. der-se-á equiparar as situações em tôda a sua plenitude, nivelando-os aos juízes de direito para efeitos de acumulação, entanto, de leǵe la a, não se nos afigura plaușível entendimento diverso.

Assim, a Comissão de Acumulação de Cargos, cćnsiderando o outro aspecto que a situação sugeria dentro dos moldes legais, houve por bem apreciar o cargo de Ministro do Tribunal de Contas dos Estados e do Distrito Federal, para efeito de acumulação, como de natureza técnica ou científica (art. 3. ${ }^{\circ}$, do Decreto n. ${ }^{\circ} 35.956$, de 2-VIII-954), pelo que se impõe a verificação, em cada caso, da existência da correlação de matérias e da compatibilidade horária, em obediência aos ordenamentos legais que disciplinam o assunto de acumulação de cargos.

A Constituição do Estado de Goiás aparentemente nos poderia sugerir uma exceção ao que acima ficou expresso, pois que aquêle diploma legal estabeleceu que um juiz de direito integrará o Tribunal de Contas do Estado, ao lado de um advogado e um contador.

Sem dúvida, tal exceção é mais aparente que real, pois o que a Constituição determinou foi uma condição para a integração do órgão, que seria constituído de cidadãos de ccnhecida idoneidade, saber jurídico, etc. ( art. $31, \S 10^{\circ}$ ), e de um juiz de direito, escolhido êste de lista tríplice de juízes organizada pelo Tribunal de Justiça local (art. $31, \S 2 .^{\circ}$ ). Ora, juiz de direito seria, pois, conditio sine qua non para o ingresso ao Tribunal de Contas, assim como advogado e contador.

Ao assumir o cargo de juiz do Tribunal de Contas (a Constituição de Goiás não dá aos membrcs de seu Tribunal o título de Ministros), perderia automàticamente o iuiz "de direito a antiga condicão, despoiando-se de suas prerrogativas peculiares de magistrado, divorciando-se do Poder Judiciário a que pertencera. e integrandc-se, com novas características, em um órgão auxiliar de outro Poder, o Legislativo.

E' certo que teria, ainda aqui, na nova função, o antigo juiz de direito. as garantias constitucionais que se conferem aos desembargadores, em 
face do que determina expressamente $\circ \S 7 .^{\circ}$ do art. 31 , da Constituição Estadual, que diz:

"Os juízes do Tribunal de Contas terão os mesmcis direitos, garantias, prerrogativas, impedimento, incompatibilidades e vencimentos dos desembargadores do Tribunal de Justiça".

Sim, os mesmos direitos, menos um, o de acumular na forma por que se permite aos juízes, isto é, segundo a exceção permitida pelo art. 96, item I, da Constituição Federal, uma vez que embora ainda com o nome de "juiz", não mais integra o Poder Judiciário, e a Carta Magna excepciona a acumulação aos juízes integrantes dêsse Poder, vale dizer aos juízes do Judiciário. A aceitação de outro cargo implicou em renúncia de todos os direitos e prerrogativas que tinha como magistrado (salvo o da contagem de tempo de serviço), sendo que o direito de exercer outro cargo, na forma do art. 96, item I, já aludidc; só the poderia ser devolvido pela Constituição Federal, a mesma que, de primeiro, the outorgou essa vantagem enquanto era órgão do Judiciário.

Nêste passo, vale relembrar o preceito contido no citado dispositivo da Magna Carta:

"Art. 96. E' vedado ao juiz:

I - exercer, ainda que em disponibilidade, qualquer outra função pública, salvo o magistério secundário e superior e os casos previstos nesta Constituição, sob pena de perda do cargo judiciário".

De modo e maneira que basta, pcr maior, o que se observou, para se verificar que a Constituição atribui áo juiz uma situação excepcional no regime de acumulação de cargos públicos. E essa exceção foi ampliada como possível conseqüência de uma impropriedade de interpretação pela Lei n. $^{\circ} 1.711$, de 28 de cutubro de 1952, quando eximiu, a acumulação do magistrado, do atendimento do pressuposto da correlação de matérias, só lhe exigindo a compatibilidade horária, o que, na prática, é de difícil verificação.

Daí se poder inferir ser excepcicnalíssima a situação do juiz em face do atual regime de acumulação de cargos públicos, o que vem contribuir ostensivamente para derrogar aquêles princípios a que de início ncs referimos, sem, nem por isso, beneficiar o magistério ou aprimorar a cultura do magistrado, objetivos que seriam de almejar, mormente no interior do País, antes conspirando contra êles, não se sabendo como vive êste ilustre "ministro universal", nem quando vive, como acode a suas obrigações, nem quando acade a elas, no clássico dizer do Padre AnTônio VIEIRA. 